\title{
Homeobox Protein DLX-1
}

National Cancer Institute

\section{Source}

National Cancer Institute. Homeobox Protein DLX-1. NCI Thesaurus. Code C133664.

Homeobox protein DLX-1 (255 aa, $27 \mathrm{kDa}$ ) is encoded by the human DLX1 gene. This protein may be involved in the development of the brain, skull and face. 